\title{
Chapter 19 \\ Towards Establishing a National \\ Mechanism to Address Losses \\ and Damages: A Case Study \\ from Bangladesh
}

\author{
Masroora Haque, Mousumi Pervin, Saibeen Sultana and Saleemul Huq
}

\begin{abstract}
This chapter presents a case study of setting up a national mechanism to address losses and damages in Bangladesh - a highly climate vulnerable country facing significant losses and damages, putting its domestic resources and expertise together to respond in a way that looks ahead and beyond the conventional responses to climate change. The efforts underway to establish the national mechanism build upon existing institutions and frameworks and are an example of collaboration across ministries, and a break-away from working in silos. The proposed mechanism is an attempt to embed climate change perspectives into disaster policymaking, to address the gaps in the current policy framework and to design a comprehensive system to for a stronger response to losses and damages from climate impacts. A national mechanism to address losses and damages not only responds to the needs within the country, it also reaffirms Bangladesh's commitment to the national targets and indicators within the Sendai Framework for Disaster Risk Reduction 2015-2030. Furthermore, the functions of the national mechanism replicate the work areas of the
\end{abstract}

M. Haque ( $\bowtie) \cdot$ S. Huq

International Centre for Climate Change and Development (ICCAD), Dhaka, Bangladesh

e-mail: masroora.haque@icccad.net

M. Pervin

United Nations Development Programme, New York, USA

S. Sultana

Bangladesh Climate Change Trust, Dhaka, Bangladesh

(C) The Author(s) 2019

451

R. Mechler et al. (eds.), Loss and Damage from Climate Change, Climate Risk

Management, Policy and Governance, https://doi.org/10.1007/978-3-319-72026-5_19 
WIM, signalling Bangladesh's commitments to the Paris Agreement. For a resource constrained LDC country, the efforts made by researchers, the development community and policymakers show resourcefulness, proactiveness and agency that can be replicated in countries facing similar vulnerabilities and resource constraints.

Keywords Loss and Damage $\cdot$ Sea level rise $\cdot$ Cyclones $\cdot$ Flooding $\cdot$ National policy $\cdot$ Disaster risk reduction $\cdot$ Adaptation $\cdot$ Technical committee

\subsection{Introduction}

Despite being heavily impacted by climate change, Bangladesh has made laudable strides in enacting laws, policies and procedures to deal with climate related hazards. The geographically small nation has been historically prone to heavy rainfall, floods, cyclones and river erosion due to its geographical location, low-lying topography and tropical climate. Bangladesh now ranks as the 6th most affected by human induced climate change according to Kreft et al. (2017). Given the country's high population density and multidimensional poverty, this risk is further exacerbated (Wright 2014). Hijoka et al. (2014) finds food productivity and food security especially threatened by climatic stressors such as heavy rainfall leading to floods, sea level rise and heatwaves. Floods cause high human and material losses, sea level rise threatens the coastal region's ability to produce rice, and heat stress has already reached critical levels unsuitable for rice production. Increased frequency and intensity of heat waves increases the spread of infectious diseases such as cholera, increases mortality and morbidity among poor and vulnerable populations.

Faced with the increasing impacts of climate change and recognising that gains in development and poverty alleviation could be severely hampered by climate change, all levels of the Bangladeshi government are committed to reducing vulnerability and building the resilience of its people. Disaster risk reduction falls under the purview of the Ministry of Disaster Management and Relief (MODMR) and climate change adaptation under the Ministry of Environment and Forests (MOEF). Responding to disasters and implementing adaptation programs also involve related ministries such as Agriculture, Health and Finance. The MODMR and the MOEF have established policies and procedures to deal with their respective portfolio and responsibilities and both ministries have committed significant domestic resources. Civil society, NGOs, community organisations, researchers, academics, development practitioners are active contributors in generating knowledge and implementing adaptation and disaster risk reduction strategies.

However, despite the success and competencies in dealing with climate-related risks, losses and damages from climate change are projected to increase and gaps exist in the current policy and response framework that needs to be addressed proactively. This chapter is a case study of the efforts of the Bangladesh government and experts collaborating to address losses and damages from climate change by establishing a new mechanism from current domestic institutional arrangements and resources. The 
proposed new mechanism will be a centralised framework for accounting, coordinating, disbursing finance, monitoring and evaluating programs that address losses and damages from climate change. The proposed mechanism will facilitate and incorporate climate induced losses and damages into both climate and disaster policies and address these losses and damages for a more comprehensive and long-term response to climate change.

This chapter is divided into four parts: (i) A discussion of the losses and damages facing Bangladesh from various climatic hazards; (ii) A presentation of policies and procedures of MoDMR including the national plan, laws governing disaster management and the procedures immediately following a disaster; as well as (iii) An elaboration of the policies of the MoEF including the laws, institutions and strategic plans that govern climate change within the ministry; and (iv) Reflection on current efforts undertaken by the government, researchers, experts and NGOs towards establishing a national mechanism to address loss and damage.

\subsection{Losses and Damages from Climate-Related Hazards Facing Bangladesh}

Bangladesh is affected by both slow- and rapid-onset climatic events and experiences, among others flooding, cyclones, drought, sea-level rise, shifting patterns in rainfall and rising temperatures (see Fig. 19.1 for a multi-hazard map). The following captures the evidence on observed and projected losses and damages ${ }^{1}$ faced by the country.

\section{Flooding}

Being the most common climatic hazard facing the country, floods inundate nearly $25 \%$ of the country every year and a severe flood occurs every 4 or 5 years submerging over $60 \%$ of the country (Nishat et al. 2013; see Fig. 19.2). Floods result in loss of lives, crops, homes and damage to infrastructure and assets. Observed data from the Bangladesh's Meteorological Department show that rainfall is becoming increasingly erratic. With increasing global temperatures above $2{ }^{\circ} \mathrm{C}$, rainfall could increase with a significant impact on flood levels (Mirza 2002).

On the other hand, Nishat et al. (2013) posit that over the years the death toll from extreme events including cyclones and flooding has decreased, as has the severity of

\footnotetext{
${ }^{1}$ Although many definitions of losses and damages exist, for the purpose of this chapter, we first break down the conc ept into the two terms: losses and damages (for definitions, see also see chapter by Mechler et al. 2018). We define losses as impacts that "are lost forever and cannot be brought back once lost, "and damages as harm to something "that can be repaired, such as a road or building or embankment." (Durand and Huq 2015). This approach highlights the different implications of the two types of impacts, and may create a policy space to enable different supportive responses. When we tie these two concepts together, Durand and Huq's definition of losses and damages holds when the costs of adaptation are not recuperated; or when adaptation efforts are ineffective, maladaptive in the long term or altogether impossible. Warner and Van der Geest and Warner's (2015) definition, "the negative effects of climate variability and climate change that people have not been able to cope with or adapt to," is also relevant in our understanding of the issue.
} 


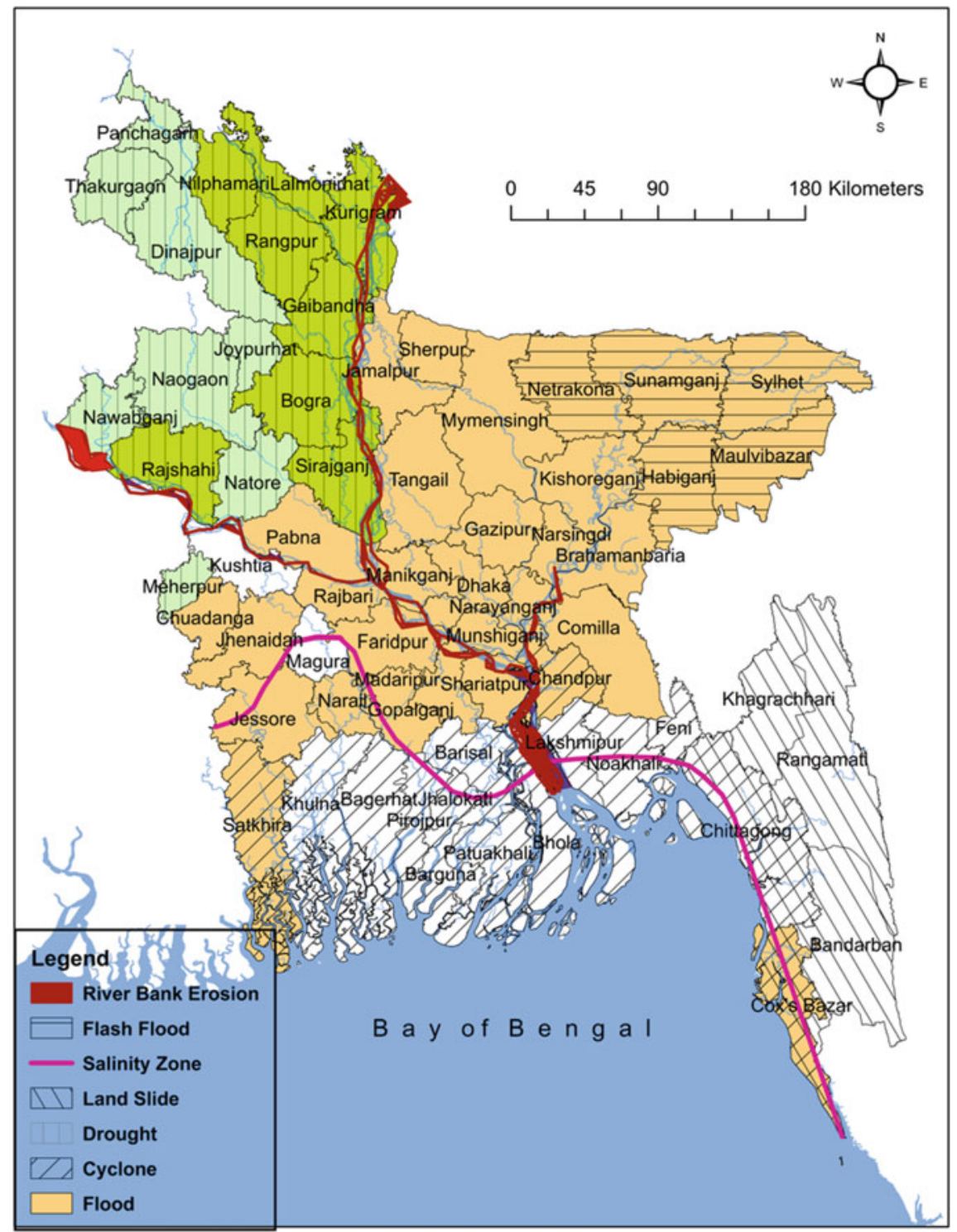

Fig. 19.1 Multi-hazard map of Bangladesh. Source Huq et al. (2016)

general impacts (see also chapter by Bouwer 2018). This can be attributed to better macroeconomic performance, increased resilience of the poor, the implementation of protective infrastructure and generally better disaster management (see Fig. 19.3 for an example of riverine flood protection). 


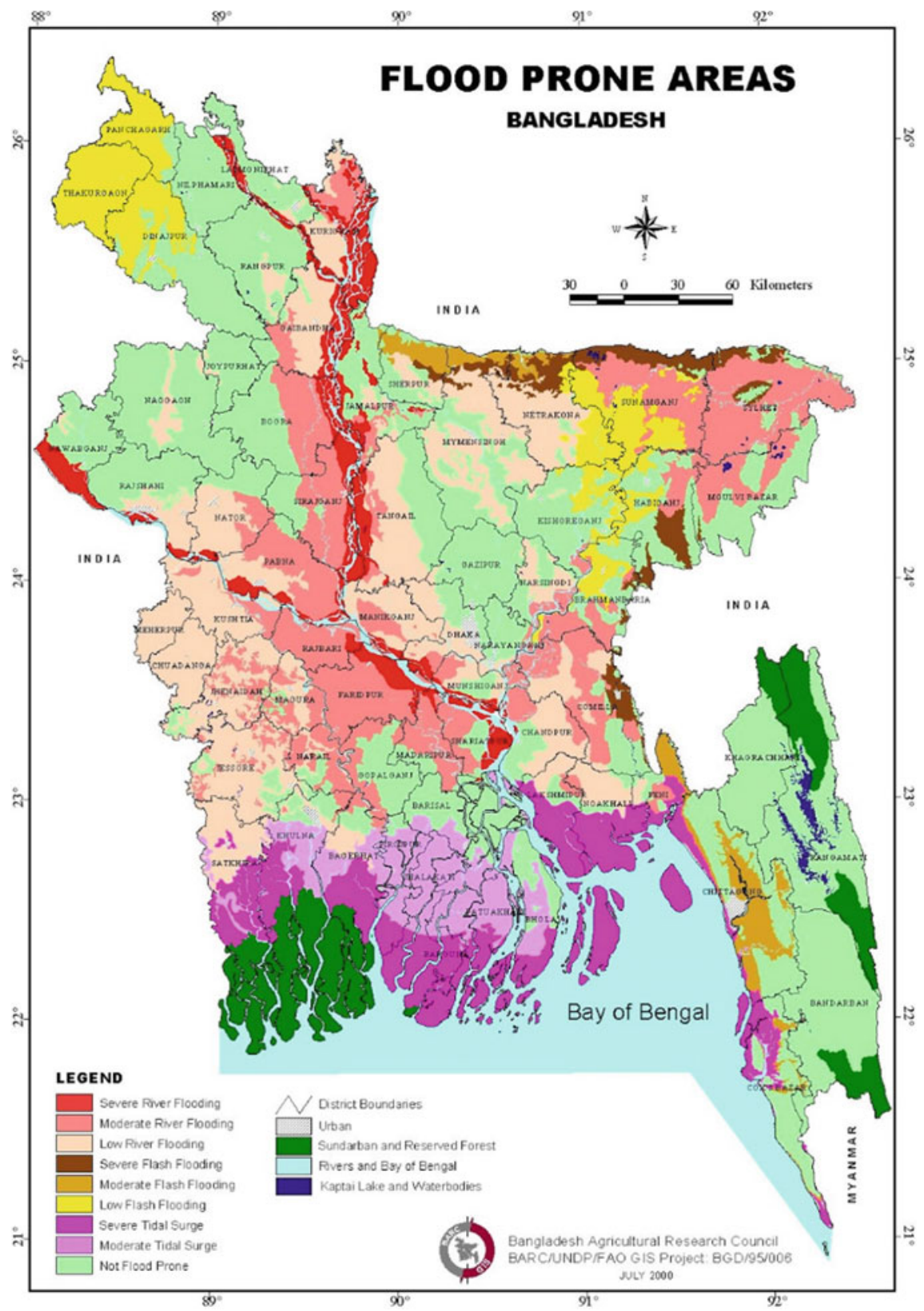

Fig. 19.2 Areas at risk of flooding in Bangladesh. Source Bangladesh Agricultural Research Council 2000 


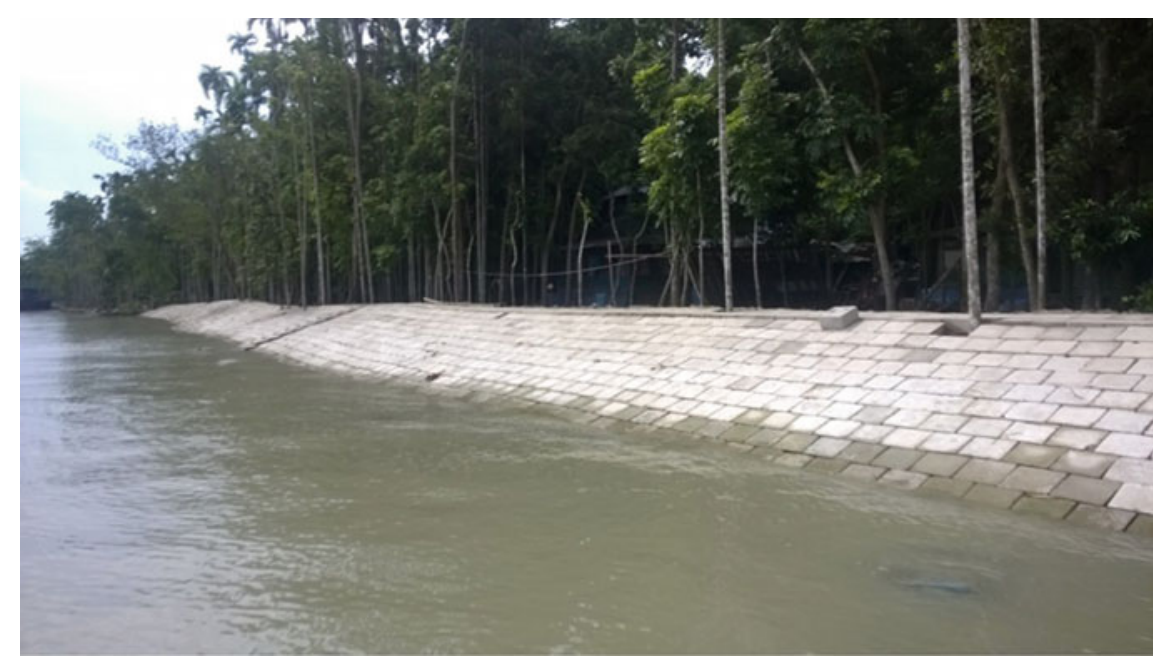

Fig. 19.3 River embankment in Bangladesh. Source Bangladesh Climate Change Trust

\section{Cyclones}

Cyclones cause untold damage to livelihoods, property and livestock of the most vulnerable people (World Bank 2010). One severe event occurs every 3 years according to the Bangladesh Climate Change Strategy and Action Plan (BCCSAP). Cyclone Sidr, which hit the Southern coast in 2007, caused total economic losses of USD 1.7 billion, or about 1.2\% of annual GDP in Bangladesh (GoB 2008). The country lost an estimated 6\% of GDP to storms from 1998 to 2009 (Wright 2014). Although the death toll from cyclones has been reduced significantly, the destruction, both economic and non-economic, is still prevalent today.

\section{Drought}

Most prevalent in the northwest of Bangladesh, drought has often caused famine in the region. The past 50 years have seen about 20 drought periods with almost roughly 23.000 sq. km of land affected by drought each year during the second dry season occurring between June to October (Nishat et al. 2013). Droughts affect about $47 \%$ of the land and $53 \%$ of the population.

\section{Sea Level Rise}

Rising sea levels impact the agricultural productivity of arable land and has an impact on livelihoods of people living in the coastal region of Bangladesh. The IPCC reports that approximately 27 million people are estimated to be at risk from sea level rise by the year 2050 in Bangladesh. According to Rabbani et al. (2013), sea levels at the coast of the Bay of Bengal, which lines the Southern coast of Bangladesh, have already risen by an average of $2.5 \mathrm{~mm}$ per year since 1950 and by an average of $5.3 \mathrm{~mm}$ per year from 1977 to 2002 . The authors also cite projections that show that by 2030 sea levels could rise by a further $30 \mathrm{~cm}$ and by 2050 by $50 \mathrm{~cm}$. Further 
projections show that by 2080 about 43 million people would be affected with a $62 \mathrm{~cm}$ rise in sea level inundating about $16 \%$ of the country.

\section{Overall Picture of Losses and Damages in Bangladesh}

The climatic impacts mentioned above translate to tangible and intangible losses and damages for the country. The World Bank (2011) estimates that climate change will lower the nation's agricultural GDP by $3.1 \%$ per year, for a cumulative $\$ 36$ billion in losses between 2005 and 2050. An Asian Development Bank report (2014) states that Bangladesh would suffer yearly economic costs equivalent to $2 \%$ of its GDP by 2050 , widening to $9.4 \%$ by 2100 . The report goes on to explain that a mix of floods, cyclones, heat stress, drought and shorter growing seasons could threaten agricultural livelihoods and food security in the country. Hijoka et al. (2014) suggest Bangladesh would see a net increase in poverty of about $15 \%$ by 2030 . Alongside obvious economic losses and damages, research in affected communities also reveal non-economic losses and damages (NELD) such as loss of biodiversity, cultural norms and practices, physical and psychological wellbeing, education and loss of ecosystem services (Andrei et al. 2014).

\subsection{Linking Climate Adaptation and Disaster in the Context of Losses and Damages}

Given these climate-induced losses and damages faced by the country, the impacts on food security and development are evident. Reducing poverty, increasing growth and graduating to middle income status by 2021 is of utmost importance to the Bangladesh government. Since 1991 and 2005 Bangladesh has made steady gains in economic growth and reduced poverty levels by $19 \%$ (Government of Bangladesh 2009). The Bangladesh Climate Change Strategy and Action Plan states that the severity and frequency of storms, floods, cyclones and drought will increase in the future stymying the country's economic growth and potentially hindering poverty reduction. Disaster risk reduction and climate adaptation are united in their mutual interest in addressing losses and damages arising from climatic events (Shamsuddoha et al. 2013). Linking climate adaptation and disaster risk reduction results in a stronger response to the climatic hazards facing the country when theory and practice are combined to address losses and damages faced by the country (Ibid). Bangladesh has made great strides in developing appropriate disaster management and climate policies and the following section highlights the policies, laws, frameworks and institutions that govern these two domains. 


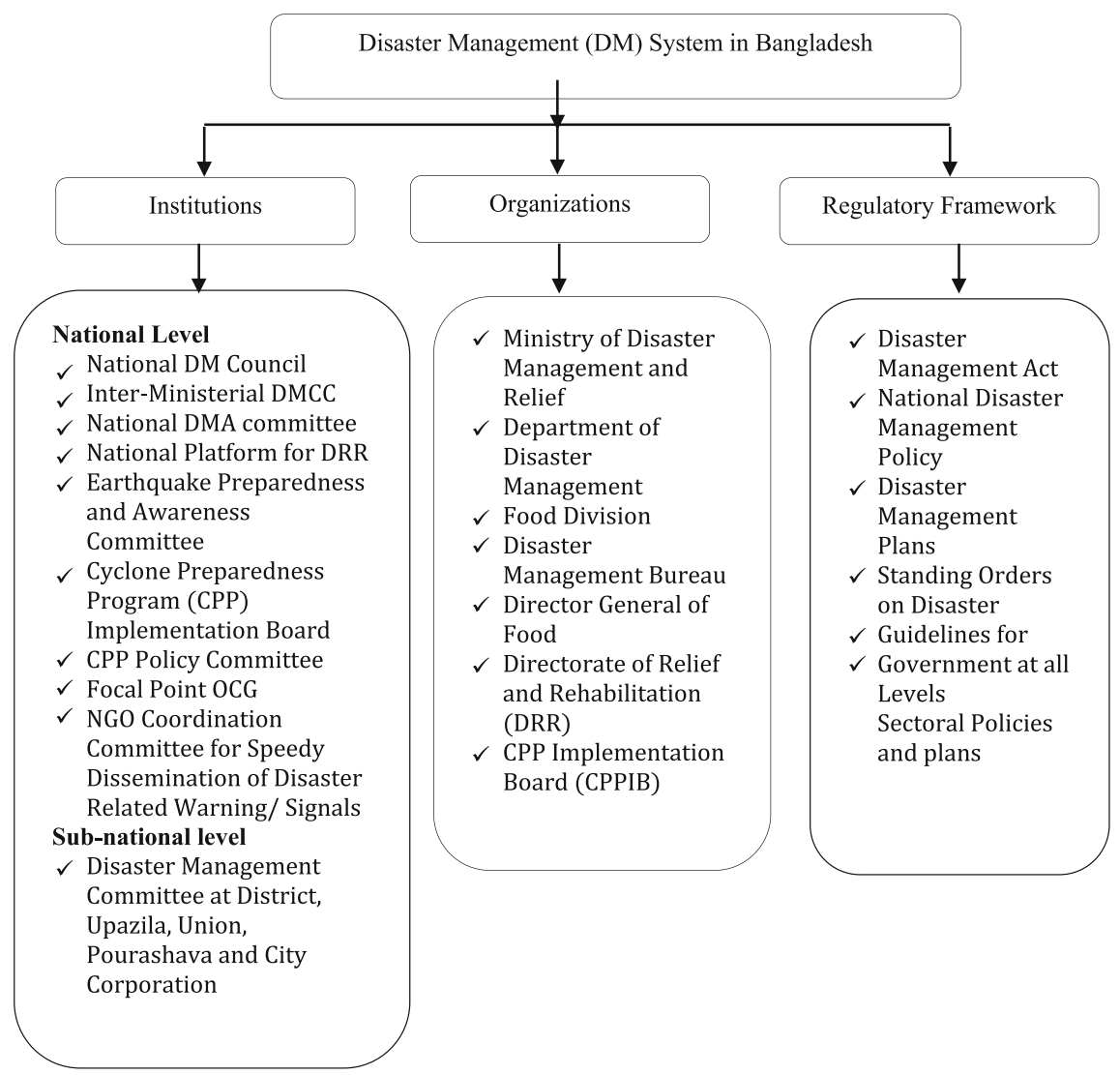

Fig. 19.4 Institutions, policy frameworks and organisations comprising the disaster management system in Bangladesh

\subsubsection{Policies and Procedures Governing Disaster Management and Relief}

Disaster risk reduction (DRR) policies in Bangladesh are well established and involve institutions at the national and sub national levels involving both political and regulatory institutions (Ibid) (see Fig. 19.4).

At the political level, the National Disaster Management Council (NDMC), led by the Prime Minister, formulates national policies. The Inter-Ministerial Disaster Management Coordination Committee (IMDMCC), led by the Minister of Disaster Management and Relief, conducts implements, coordinates and supervises the work of those implementing relevant policies. At the regulatory level, the Ministry of Disaster Management and Relief (MoDMR) is the primary governing body that aims to pursue comprehensive risk reduction policies and ensure food security to 
affected communities during disasters (MoDMR 2014). The ministry's main functions include: (i) Formulating the laws, policies and action plans for disaster risk reduction, emergency response and disaster management; (ii) Preparing policies and plans for urgent humanitarian assistance and rehabilitation program, preparation and preservation of all social safety net program; (iii) Preparing disaster risk reduction plans, undertaking activities for training and research, and coordination, monitoring and evaluating activities among local, regional and international development partners; (iv) Undertaking humanitarian assistance to ensure food security through the implementation of food for work program (FFW), gratuitous relief (GR) and vulnerable group feedings program (VGF); and (v) Ensuring employment for the ultra-poor during lean period of the year to reduce poverty risk and vulnerability.

The Department of Disaster Management (DDM) is the technical arm of the MoDMR which delivers and implements interventions on the ground. The DDM ensures that disaster risk reduction (DRR) considerations are mainstreamed into the policies, plans and programmes of related ministries and departments. It further coordinates research, capacity building, and awareness raising on DRR related activities (Shamsuddoha et al. 2013). Key development policies and plans of the government such as the Bangladesh Perspective Plan 2010-2021, Sixth Five Year Plan 2011-2015 and National Sustainable Development Strategy (NSDS) emphasise implementing the National Plan on Disaster Management (NPDM) in line with the national plan. The Seventh Five Year Plan 2016-2020 calls for building resilience of the poor and reducing their exposure and vulnerability to geo-hydro-meteorological hazards, environmental shocks, man-made disasters, emerging hazards and climate related extreme events.

The Disaster Management Act of 2012 aims to mitigate the overall impacts of a disaster and reduce vulnerability. The Act governs post disaster rescue and rehabilitation programs, humanitarian assistance to enhance the capacity of poor and disadvantaged, programs undertaken by various government and non-government organisations (GoB 2012). The aim of Disaster Management Policy is to strengthen the capacity of the Bangladesh disaster management system to reduce unacceptable risk and improve response and recovery management at all levels. It makes references to relevant sector policies, operational guidelines and procedures.

The Standing Order on Disaster (SOD) was first issued in 1997 to act as a guidebook during an emergency for concerned ministries, departments, line agencies, local government bodies and communities to understand and perform their duties and responsibilities during a disaster. The SOD has been revised in 2010 to include sector development plans, and those having emergency management responsibilities to prepare their own contingency plans and train their staff accordingly. Moreover, to maintain coordination amongst the concerned ministries, departments, line agencies, local government bodies (LGD) and communities, the government has formulated a set of mechanisms for council and committees from national down to the grass-root levels. Established by the National Disaster Management Council, the National Plan for Disaster Management 2010-2015 (NPDM) aims to reduce the risk of people, especially the poor and the disadvantaged, from the effects of natural, environmental and human induced hazards. The plan puts in place an efficient emergency response 
system capable of handling large scale disasters and has been embedded in government high level policy and operation documents.

The Disaster Management Bureau (DMB) performs specialist functions and ensure coordination with line departments/agencies and NGOs by convening meetings every three months with teams of the Disaster Management Training and Public Awareness Building Task Force (DMTATF), the Focal Point Operational Co-ordination Group on Disaster Management (FPOCG), the NGO Co-ordination Committee on Disaster Management (NGOCC), and the Committee for Speedy Dissemination of Disaster Related Warning Signals (CSDDWS). Coordination at district, thana and union levels (sub national levels) are done by the respective District, Sub-district (Thana) and Union Disaster Management Committees. The DMB will render all assistance to them by facilitating the process. Inter-related institutions, at both national and sub-national levels have been created to ensure effective planning and coordination of disaster risk reduction and emergency response management.

\subsubsection{History of Damage Assessment and Current Practices}

After Cyclone Sidr in 2007, the Local Consultative Group (the forum for development dialogue and donor coordination) agreed to conduct a Joint Damage-Loss and Needs Assessment (JDNLA). This assessment identified priority areas to support the Government of Bangladesh in cyclone recovery efforts and recommended interventions for a long-term disaster management strategy. Based on the assessment, a 15-year long-term strategic plan of action was developed supported by the World Bank. A Damage-Loss and Needs Assessment (DNA) cell was established within the DMB to provide emergency relief, rehabilitation, and reconstruction for victims of natural disasters. The cell is responsible for strengthening the existing data collection by using a standardised template (FORM-D) and to build the capacity of relevant agencies and administrative levels to conduct DNA. In 2011, after the cyclone Mahasen, the Department of Disaster Management gradually shifted to a formal damage and loss assessment in the name of Joint Needs Assessment (JNA). The JNA approach has embedded in it a national coordination mechanism and has the buy-in of a broad range of stakeholders including the DDM and MoDMR. The JNA initiative is now managed by CARE for the humanitarian community in Bangladesh with ACAPS working as a key partner providing technical inputs and assessment coordination. DDM in partnership with INGOs, CDMP II and other government departments developed loss and damage resource maps using the $4 \mathrm{~W}$ (what, where, when, and who) database to make disaster information and assessments more available.

According to Shamsuddoha et al. (2013), under the MoDMR, the Comprehensive Disaster Management Programme (CDMP), one of the largest initiatives ever implemented in the country to deal with disaster management, is "currently undertaking efforts to "harmonise" DRR and CCA in its work to reduce disaster risk. In addition, 


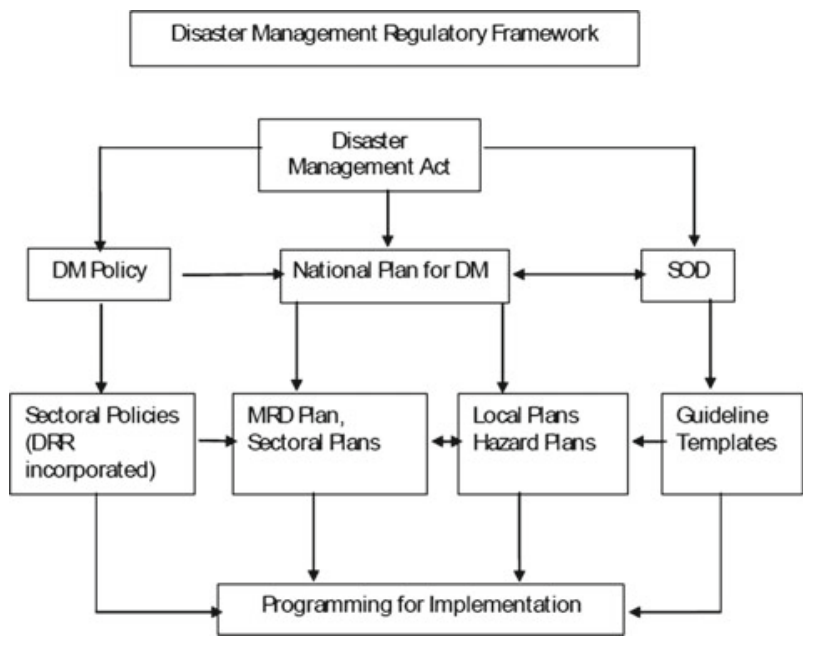

Fig. 19.5 Disaster Management Regulatory Framework of Bangladesh. Source Shamsuddoha et al. (2013)

the CDMP has begun to recognise the importance of addressing loss and damage in its agenda" (p. 15).

The Local Disaster Risk Reduction Fund (LDRRF), a component of CDMP provides some resources and financial support to the most vulnerable communities affected by a climatic disaster. Approximately USD 5 million was disbursed to local governments in the 2013-2014 fiscal year from this fund. In addition to the LDRRF, the MoDMR also runs several social safety net programs meant to support climate affected communities such as Food For Work (FFW), Test Relief, Bridge and Culverts (FFW), Execution of Risk Reduction Programme, Relief and Rehabilitation Programme, Vulnerable Group Feeding (VGF) and Vulnerable Group Development (VGD). Other disaster and relief related programmes include the National Relief Fund and Prime Minister's Relief Fund (Huq et al. 2016) (Fig. 19.5).

\subsubsection{Climate Change Policies in Bangladesh}

Bangladesh was an early mover amongst Least Developed Countries (LDCs) to create a National Adaptation Programme of Action (NAPA) and a dedicated national policy on climate change. Stemming from the NAPA process, the Ministry of Environment and Forests, along with DFID and other partners, formulated the Bangladesh Climate Change Strategy and Action Plan (BCCSAP) in 2009. The document guides climate change policies, programs and projects in the country and is in line with the government's vision to eradicate poverty and achieve economic prosperity for its people. The document stresses, 
We will achieve this through a pro-poor, climate resilient and low-carbon development, based on the four building blocks of the Bali Action Plan-adaptation to climate change, mitigation, technology transfer and adequate and timely flow of funds for investment, within a framework of food, energy, water and livelihoods security (BCCSAP 2009, p. 2).

The BCCSAP identifies six thematic areas of work where interventions to adapt and mitigate climate change are to be focused: (1) food security, social protection and health; (2) comprehensive disaster management; (3) infrastructure; (4) research and knowledge management; (5) mitigation and low-carbon development; (6) capacity building and institutional strengthening. There are 44 programs identified under these six areas. Although there is no holistic mention of addressing Loss and Damage in the way it is defined in this chapter, the pillar on Comprehensive Disaster Management lends some scope for synergies. The document does identify a programme for risk management against loss of income and property under the comprehensive disaster management theme. One of the programs of the Comprehensive Disaster Management theme is to manage risk against loss of income and property. The objective of this program is "to put in place an effective insurance system for risk management against loss of income and property" (BCCSAP 2009). The program promotes working with NGOs and insurance companies on three action areas:

1. Devise an effective insurance scheme for losses in property due to climate change impacts

2. Develop an effective insurance scheme for loss of income from various sources to persons, households and enterprises

3. Pilot the insurance schemes and if successful, establish insurance systems for lowering risk of adverse impact of climate change (Ibid).

Climate migration and displacement is an action area of the work plan of the Warsaw International Mechanism (WIM). The BCCSAP makes several references to migration, cautioning that displacement of millions of people, livelihoods and long-term health of the population will be affected under the worst-case scenario.

\subsubsection{Government Funds to Support the Climate Change Strategy and Action Plan (BCCSAP)}

To fund the projects and activities under the BCCSAP, two funds were established by the government in 2010, the Bangladesh Climate Change Trust Fund (BCCTF) from the government's own resources and the Bangladesh Climate Change Resilience Fund (BCCRF) from donor funding and managed by the World Bank. 


\section{The Bangladesh Climate Change Trust}

Climate change work in the government, falls under the jurisdiction of the Ministry of Environment and Forests (MOEF). The Climate Change Unit (CCU) under the MoEF coordinates and facilitates the implementation of the BCCSAP under the overall guidance of the National Environment Committee chaired by the Prime Minister and the National Steering Committee on Climate Change (Shamsuddoha et al. 2013). The CCU's main objective is to use the trust fund, provide management, administrative and monitoring support to the trustee board and its technical committee. In 2010, the government enacted the Climate Change Trust Act to conduct the functions of the BCCTF according to the Bangladesh Climate Change Trust Annual Report 2014-2015. The Bangladesh Climate Change Trust (BCCT) and its functions are governed by a 17-member Trustee Board which is the highest decision-making body for the Fund. It comprises of the minister of Ministry of Environment and Forests as the chair and 16 other members including 10 ministers/state ministers, cabinet secretary, governor of the central, finance secretary, member of Planning Commission and two experts appointed by the government. The secretary, Ministry of Environment and Forests, acts as the board's member-secretary (Ibid). To assist the trustee board, there is a technical committee headed by the Secretary, Ministry of Environment and Forests. It committee comprises thirteen members including experts/representatives from the Planning Commission, Department of Environment, Department of Forest, and Centre for Environmental and Geographic Information Services (CEGIS) and social organisations/NGOs working on climate change. The technical committee provides recommendations to the trustee board on the different projects submitted for approval.

According to the 2014-105 Annual Report of the Bangladesh Climate Change Trust, specific functions of the BCCT include overall management of the trust fund; to provide administrative support to the trustee board and the technical committee; to send project proposals to the technical committee (after preliminary screening) and to place the proposals to the trustee board after the recommendation from the technical committee; implementing the decision of the trustee board; and monitoring and evaluation of projects.

\section{The Bangladesh Climate Change Trust Fund (BCCTF)}

The Trust Fund created in fiscal year 2009-10 specifically funds the 44 programs specified under the six thematic areas of BCCSAP. $66 \%$ of the funding from the trust fund is utilised in the projects and $34 \%$ is held in reserve in a fixed deposit account (Ibid). About $77 \%$ of all climate finance projects in Bangladesh are financed from the domestic budget (Faruque and Khan 2013). The Government of Bangladesh has to date allocated BDT 3100 crore (US\$400 million approximately) to BCCTF during the last eight fiscal years (Table 19.1). 
Table 19.1 Annual allocations to the trust fund are as follows (BCCT)

\begin{tabular}{l|l|l}
\hline Fiscal year & Allocation (BDT in crore) & $\begin{array}{l}\text { Allocation (USD in millions, } \\
\text { approximate figures) }\end{array}$ \\
\hline $2009-2010$ & 700 & 902 \\
\hline $2010-2011$ & 700 & 902 \\
\hline $2011-2012$ & 700 & 902 \\
\hline $2012-2013$ & 400 & 515 \\
\hline $2013-2014$ & 200 & 258 \\
\hline $2014-2015$ & 200 & 258 \\
\hline $2016-2017$ & 100 & 129 \\
\hline Total & 100 & 129 \\
\hline
\end{tabular}

Source Bangladesh Climate Change Trust Fund

As per Climate Change Trust Act, 2010, a maximum of $66 \%$ of the allocated amount can go towards the projects. The remaining $34 \%$, approximately totaling USD 135 million or BDT 1054 crore, is kept in a fixed deposit account in various private and public banks. One of the reasons why the government has kept a certain portion in reserve is that in the future the interest can create the possibility of funding climate change projects without allocating an amount from the annual budget. As of July 2016, 431 projects have been undertaken-368 projects are being implemented by the government, semi-government and autonomous agencies, 63 projects are being implemented by NGOs. A GCF accredited national organisation called the Palli Karma-Sahayak Foundation (PKSF) manages the portion of funds that goes towards NGOs. Projects have to satisfy the environmental and social safety standards as recommended by the technical committee in order to receive funding from the BCCTF. Major projects under the BCCTF include construction of coastal sea dykes, embankments, river protection work; development of cyclone resilient houses and multipurpose cyclone shelters in vulnerable areas; establishing agro-met stations; water supply for irrigation; excavation/re-excavation of canals and construction of drains at different rural municipalities; afforestation projects to protect coastal areas and conserve biodiversity; biogas plants; improved cook-stoves; solar home systems are mitigation projects funded from the trust fund. In the fiscal year 2014-15 the Ministry of Local Government and Engineering department was awarded the highest number of projects, followed by the Ministry of Water Resources (see Fig. 19.6).

The financial management and accounting procedures are maintained in strict adherence to existing government financial rules. BCCTF has been audited by the Office of the Comptroller and Auditor General and no objection has been received. There is an Internal Audit Committee headed by the Secretary of BCCT that audits all files with financial implications and adopts corrective measures. The external audit is done by the Office of the Comptroller and Auditor General of Bangladesh as per the direction of Climate Change Trust Act of 2010. 


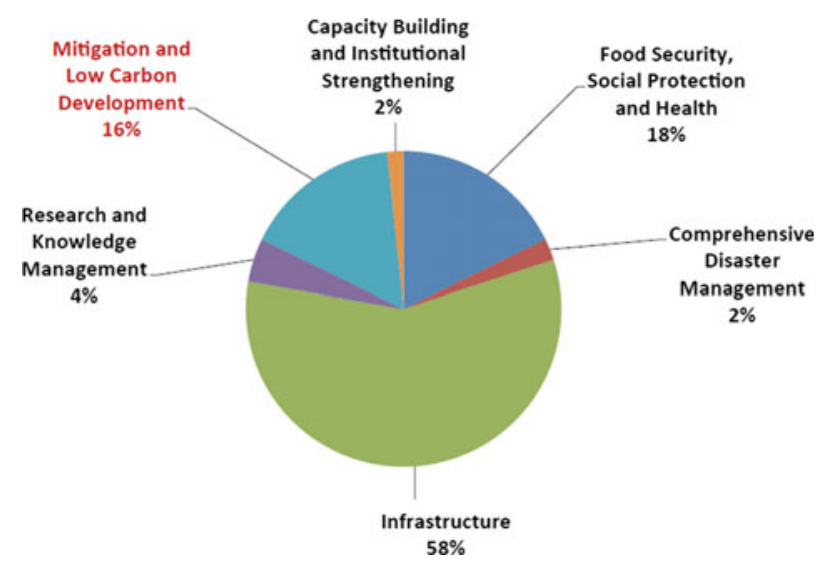

Fig. 19.6 Allocation of funding for projects by the Bangladesh Climate Change Trust Fund (BCCTF). Source Kamruzzaman (2015)

The monitoring of projects funded by the BCCTF are the responsibility of the concerned implementing ministries. The Monitoring and Evaluation Branch in BCCT also receives monthly progress report from the project directors, sends inspection team for field visits, and convenes regular monitoring meetings with Project Directors. Headed by the Managing Director of the Trust, there is also a Monitoring Committee that analyses the monitoring reports and puts forward its recommendation for proper implementation of the projects. According to the Trust's website, local administration is involved in the monitoring process to ensure local oversight. The administrative officers and elected representatives also discuss these projects in the district coordination meetings. Completed projects are evaluated by the Implementation Monitoring and Evaluation Division (IMED) of the Ministry of Planning.

\subsection{Towards Establishing a National Mechanism to Address Climate Induced Losses and Damages in Bangladesh}

Both economic and non-economic losses and damages from climatic events are being experienced in Bangladesh currently, with the impacts expected to grow according to future projections. As explained in the first section of this chapter, climatic events are changing their patterns, frequency and intensity, which is expected to negatively affect the country's economic growth, food security and public health. The main gap that exists in the current climate-related policy framework in Bangladesh is a lack of legislative, institutional and policy-related mechanism that explicitly address climate induced losses and damages. A system that documents or accounts for the extent of losses and damages, both monetary and non-monetary and provides for longer term 
support does currently not exist. Losses and damages affecting the most vulnerable communities are addressed tangentially and disparately organised through MoEF and MoDMR. To respond to the experienced and future losses and damages a proactive and robust system of collecting evidence, proving support to communities whose livelihoods, assets and quality of life have been most affected by climate change is much needed.

Over the years, Bangladesh has well established, but separate laws, institutions, rules and procedures to respond to climatic events. DRR and adaptation share a common mandate to reduce vulnerability and enhance the resilience of affected populations. Policy makers in the MoDMR and MoEF are both concerned with protecting lives, livelihoods, food security and minimising of losses and damages of the most at-risk populations. Despite these commonalities, the disaster and climate change policy realms in Bangladesh operate in silos, with little collaboration or cooperation. Shamsuddhoa et al. (2013) highlights that "bureaucratic demarcation of responsibility" and "institutional silos" of climate adaptation and DRR policy-making hinder cross-sectoral cooperation. To address losses and damages more effectively and efficiently, climate adaptation approaches and perspectives need to be integrated into DRR policy-making.

The competency and success of disaster reduction strategies in Bangladesh have focused on immediate response and relief. There is an expressed need for communities on the frontlines to adapt and receive support for the impacts of climate change that they cannot adapt to. Long term support to rebuild and build back better requires the integration of DRR and climate adaptation approaches and perspectives. According to Shamshuddoha et al. (2013), "the incorporation of DRR expertise in implementation could help to increase the pace at which CCA efforts move from planning to action DRR can also learn from the long-term perspectives of CCA in order to ensure that DRR activities align with shifting climatic realities, and not just historical experience" (p. 27).

Slow onset events, salinity intrusion, increased intensity of cyclones and noneconomic losses and damages are not accounted for in the current national policies of the MoDMR. There is currently no provision in the legislative framework in either MoDMR and MoEF that address slow onset events such as sea level rise and non-economic losses and damages. Different projections show various scenarios of inundation and the population affected under sea-level rise and there is a need to systematically understand, document and prepare for this hazard. Non-economic losses and damages have not received mention in policy frameworks and procedures, but evidence shows that there are profound psychological, environmental, social and cultural impacts of losses and damages from a variety of climatic stressors. Current disaster preparedness procedures do not take into account future climate projections and the systems that need to be put in place so that losses and damages are minimised in the future.

The above highlight the need to address the gaps in the current policy and legislative framework and build a more robust response to climate-induced losses and damages. Efforts are now underway in Bangladesh to bring policy-makers in MoDMR and MoEF in coordination with one another to build a national mechanism that 
addresses losses and damages more holistic and comprehensive manner. A scoping paper (Huq et al. 2016) on developing a national mechanism offers a framework to address Loss and Damage and documents the current efforts being undertaken to establish such a system. According to Huq et al. (2016), to develop local, national and international policy and institutional frameworks to address Loss and Damage, it is first essential to identify, measure and characterise losses and damages faced in Bangladesh. Understanding and quantifying losses and damages experienced from various climatic events, taking into account the social, economic and geographical contexts in which they occur is the first step towards building a national mechanism. The scoping paper argues for a centralised mechanism that facilitates the coordination between MoDMR and MoEF, disburse financing, monitor and evaluate programs to address climate induced losses and damages in Bangladesh.

Over the years, Bangladeshi policymakers and practitioners have acquired knowledge and expertise on disaster management and climate adaptation, making them highly capacitated to plan, strategise and execute climate policies. Both the politi$\mathrm{cal} /$ bureaucratic and technical spheres involved in the climate and disaster sector are motivated and committed to preventing the worst of climate impacts impeding the development of the nation. The Bangladesh delegation is an active member of the LDC negotiating bloc in the UNFCCC. Moreover, a senior bureaucrat of the MoEF currently sits on the Executive Committee of the Warsaw International Mechanism on Loss and Damage (WIM).

In 2012 the Government of Bangladesh initiated the "Loss and Damage in Vulnerable Countries Initiative," a pioneering study on understanding the issue. The initiative commissioned a number of studies on losses and damages, which brought together climate change researchers, academics, practitioners and NGOs and deepened their knowledge, capacity and expertise on this issue. The initiative created awareness, understanding and a systematic body of work that laid the foundation for an intellectual and practical understanding of losses and damages.

The human and institutional capacity and common mandate of the MoEF and MoDMR to reduce vulnerability and build resilience means that there is much potential to establish a mechanism to address climate Loss and Damage. This reserve fund of approximately USD 135 million or $34 \%$ of the Bangladesh Climate Change Trust Fund creates a financial resource base to setup such a mechanism with domestic resources. Huq et al. (2016) recommends developing the national mechanism on Loss and Damage based on the country's current adaptation and disaster risk finance frameworks. This section further highlights the current efforts being undertaken in the country to establish such a national mechanism to account for climate induced losses and damages more holistically looking inward at the competencies that already exist in the country. 


\subsubsection{Unpacking the Warsaw International Mechanism on Loss and Damage in the National Context of Bangladesh}

On February 16, 2016, the MoDMR hosted a workshop on Loss and Damage supported by the Climate and Development Knowledge Network (CDKN), Action Aid Bangladesh, C3ER and NACOM in Dhaka. The event was primarily targeted towards MoDMR staff and aimed at helping staff understand how national mechanism to address Loss and Damage could form part of the disaster risk reduction strategy (Khan 2016). The workshop brought together the minister of MoDMR, senior bureaucrats, policymakers, field professionals from MoMDR along with civil society, researchers and experts working on DRR and loss and damage to start discussions on how the WIM can be translated at the national level. The workshop identified gaps, synergies and opportunities in addressing losses and damages within the MoDMR's DRR framework and the way forward on establishing a national mechanism. Highlights of the discussions included Strengthening the assessments of key sectors impacted by climate disasters by modifying current disaster assessments conducted by MoDMR through various scientific tools; Improving coordination and monitoring among relevant institutions and ministries to address and account for loss and damage; Establishing a national coordination cell and a legal framework to implement climate induced loss and damage related policies; The need for adequate financial support to conduct research, gather and quantify data on loss and damage. The workshop was a first step to bring on board key stakeholders to understand and agree on establishing a national system/mechanism to deal with climate induced losses and damages. The Ministry of Disaster Management and Relief has agreed to lead the process of the mechanism with input and support from the Ministry of Environment and Forests, Ministry of Land, Ministry of Water Resources.

\subsubsection{National Consultations}

Following the aforementioned workshop on loss and damage, four sub national consultations took place in the Sylhet, Rangpur, Khulna and Chittagong districts with relevant stakeholders including the Deputy Commissioners of MoDMR of those regions in September 2016 (Huq et al. 2016). These nationwide consultations took stock of the current practices to address losses and damages from disasters, possible responses when climatic events are intensified and the support needed from the national level to aid the local level to respond more effectively. Since climate impacts are experienced at the local level, these regional consultations were extremely valuable in gathering the local level's insight on how the mechanism should be devised (Huq et al. 2016). Recommendations from the regional consultation included:

- A need for DRR responses within the MoDMR to include protection of assets and livelihoods of those affected by climatic disasters; 
- A need for enhanced coordination at the local level;

- Establishment and maintenance of a comprehensive database of people and assets. Related to the database, a pre-assessment mechanism is recommended;

- Education and awareness of climate induced losses and damages;

- Human and financial resources dedicated to build capacity of local government to deal with increased frequency of disasters or a large scale single event (Ibid).

Following the regional consultations, a national consultation took place in October 2016, organised jointly by CARE Bangladesh and Action Aid Bangladesh with key MoDMR policymakers including the Director General of the Department of Disaster Management in Dhaka. The consultation presented the findings of the fieldlevel consultations along with discussions on taking the mechanism forward. Several areas of further research emerged from the consultation which look to better understand Loss and Damage in the country and the information needed to build a holistic national mechanism. The central recommendation that emerged from this consultation was that the Government of Bangladesh should consider setting up a national mechanism on Loss and Damage through a new technical team with specific terms of references. Also presented at the consultation was a scoping study which articulated the details on the process of establishing a national mechanism on losses and damages prepared by ActionAid Bangladesh, CARE Bangladesh, the International Centre for Climate Change and Development and Nature Conservation Management. The study included proposed functions and activities of the national mechanism and an institutional structure comprising of a national steering committee and a technical working group to oversee the development of the mechanism.

\subsubsection{National Steering Committee and Technical Working Group}

The scoping study proposed to establish a national steering committee comprising of high level policy makers and relevant experts to oversee the development of the mechanism. The mandate of the steering committee would be to formulate positions for the UNFCCC negotiations on Loss and Damage, make decisions on national policy for Loss and Damage and oversee, approve and monitor the work of the technical working group (Huq et al. 2016) (see Fig. 19.7).

The scoping study also recommends forming a technical working group comprising of sector experts to conduct specific activities. The tasks of the working group include: to provide technical guidance/recommendations to national steering committee; to identify thematic areas and activities of the national mechanism; to develop a work plan to implement the activities of the thematic areas identified; to recommend a panel of experts, approving their work plan and monitoring and evaluating the of implementation work plans. 


\section{Oversight: National Steering Committee}

Functions
A framework for enhancing understanding and knowledge related to climate impacts,
vulnerabilities and loss and damage;
The tools and methodologies for comprehensive risk assessment; Nationally appropriate
approaches of comprehensive risk management, including risk reduction, risk retention
and risk transfer etc;
- The approaches for addressing residual loss and damage, including permanent and
irreversible loss and damage;
- A framework for developing early warning systems and emergency preparedness;
- Financial instruments to facilitate works related to loss and damage and pay
compensation;
- Nationally appropriate technologies and to facilitate to access global technologies;
- Capacity building framework;
A framework for enhancing resilience of communities, livelihoods and ecosystems;
- Nationally appropriate specific approaches to address loss and damage associated with
slow onset events;
- Nationally appropriate specific approaches to address non-economic loss and damage;
A clearing house for data and information;
- A framework for facilitating research and study on loss and damage;
- Policies, plans, legislations and institutions for migration and displacement and to
collaborate with regional and international efforts;
- Sectoral policies, plans, legislations and institutions to mainstream loss and damage;
- Specific national policy and legislation for loss and damage;
A collaborative framework between National Mechanism and the WIM.

Fig. 19.7 Proposed functions of the national mechanism to address climate induced loss and damage. Source Huq et al. (2016)

\subsection{Conclusions}

This chapter highlighted the case of Bangladesh, a highly vulnerable country facing significant losses and damages, which is putting its domestic resources and expertise together to respond in a way that looks ahead and beyond the conventional responses to climate change. The actions taken to establish a national mechanism to address losses and damages builds upon existing institutions, mechanisms and frameworks and is an example of collaboration across ministries, departments and a break away from working in silos. Working towards a holistic mechanism embodies a systematic approach to understanding the different perspectives of relevant stakeholders, where the gaps lie and crafting a system to address the gaps for a stronger response to loss and damage from climate impacts. The coordination of the work through the Ministry of Disaster Management and Relief (MoDMR) and Ministry of Environment and Forests (MoEF) signify that the issue of climate change has broader acceptance and recognition among policymakers in the Bangladesh. Recognising that climate change is not just an environmental issue, but it has implications on the work of the disaster community, MoDMR's activities described above signifies an acceptance 
of responsibility to respond to Loss and Damage from climate change. Moreover, establishing the mechanism will significantly aid in much needed coordination and collaboration between MoDMR and MoEF. As of April 2018, the Government of Bangladesh has formed an inter-ministerial committee headed by MoDMR to develop a 2-year pilot phase for exploring the National Mechanism on Loss and Damage. A concept note has already been developed and a detailed workplan for the 2-year pilot phase is being developed. The government of Bangladesh intends to make a public announcement of the National Mechanism on Loss and Damage at COP24 in December 2018.

A national mechanism to address Loss and Damage not only responds to the needs within the country, it also reaffirms Bangladesh's commitment to the national targets and indicators within the Sendai Framework for Disaster Risk Reduction 2015-2030. Furthermore, the functions of the national mechanism replicate the work areas of the WIM, signalling Bangladesh's commitments to the Paris Agreement. For a resource constrained LDC country, the efforts made by researchers, the development community and policymakers display a resourcefulness and creativity that can be replicated in countries facing similar vulnerabilities and resource constraints.

\section{References}

Andrei S, Rabbani G, Khan HI, Haque M, Ali DE (2014) Non-economic loss and damage caused by climatic stressors in selected Coastal Districts of Bangladesh. http://gobeshona.net/publicati on/non-economic-loss-damage-caused-climatic-stressors-selected-coastal-districts-bangladesh/. Accessed 7 June 2017

Asian Development Bank 19 August 2014. Bangladesh Could See Climate Change Losses Reach Over 9\% Of GDP—Report. Asian Development Bank [online]. https://www.adb.org/news/bang ladesh-could-see-climate-change-losses-reach-over-9-gdp-report

Bangladesh Agricultural Research Council (2015) Areas at risk of flooding in Bangladesh. http:// www.thebangladesh.net/flood-maps-of-bangladesh.html\#map-2. Accessed 7 April 2018

Bouwer LM (2018) Observed and projected impacts from extreme weather events: implications for loss and damage. In: Mechler R, Bouwer L, Schinko T, Surminski S, Linnerooth-Bayer J (eds) Loss and damage from climate change. Concepts, methods and policy options. Springer, Cham, pp 63-82

Durand A, Huq S (2015) Defining loss and damage: key challenges and considerations for developing an operational definition. In: The International Centre for Climate Change and Development. ICCCAD www.icccad.net/wp-content/uploads/2015/08/Defininglossanddamage-Final. pdf. Accessed 7 June 2017

Faruque DA, Khan MI (2013) Loss and damage associated with climate change: the legal and institutional context in Bangladesh. In: Loss and damage in vulnerable countries initiative. Available via www.lossanddamage.net, www.loss-and-damage.net/download/7114.pdf. Accessed 7 June 2017

Government of Bangladesh (GOB (2008) Cyclone Sidr in Bangladesh Damage, Loss, and Needs Assessment for Disaster Recovery and Reconstruction. Available via Reliefweb. http://reliefwe b.int/report/bangladesh/cyclone-sidr-bangladesh-damage-loss-and-needs-assessment-disaster-re covery-and. Accessed 7 June 2017 
Government of Bangladesh (2009) Bangladesh Climate Change Strategy and Action Plan. Available via Climate Change Cell. www.climatechangecell.org.bd/Documents/climate_change_strategy2 009.pdf. Accessed 7 June 2017

Government of Bangladesh (GoB) (2010) Standing Order on Disasters. Available via Local Consultative Group. www.lcgbangladesh.org/DERweb/doc/Final\%20Verion\%20SOD.pdf. Accessed 7 June 2017

Government of Bangladesh (GoB) (2012) Bangladesh Disaster Management Act. Available via EMI. http://emi-megacities.org/?emi-publication=bangladesh-disaster-management-act-of-2 012. Accessed 7 June 2017

Government of Bangladesh (GoB) (2014) Bangladesh Climate Change Trust Fund: Fund use guidelines. Available via http://www.bcct.gov.bd/index.php/projects/fund-use-guidelines. Accessed 7 June 2017

Government of Bangladesh (GOB) (2015) Climate Change Trust Annual Report 2014-2015. http:// www.bcct.gov.bd/index.php/publications-downloads. Accessed 7 June 2017

Hijioka Y, Lin E, Pereira JJ, Corlett RT, Cui X, Insarov GE, Lasco RD, Lindgren E, Surjan A (2014) Impacts, adaptation, and vulnerability. Part B: Regional aspects. Contribution of working group II to the fifth assessment report of the intergovernmental panel on climate change

Huq S, Kabir F, Khan MH, Khan MHI, Hossain T, Hossain JB, Pasternak L, Nasir N, Hadi T, Mahmud S, Mahid Y (2016) National mechanism on loss and damage in Bangladesh: Scoping Paper. Available via Scribd. https://www.scribd.com/document/329856845/Bangladesh-loss-an d-damage-proposal. Accessed 7 June 2017

Kamruzzaman M (2015) National Climate Finance: Performance of Bangladesh Climate Change Trust Fund [PowerPoint Presentation]. Gobeshona Conference for Climate Change Research in Bangladesh. Available via http://gobeshona.net/wp-content/uploads/2014/09/National-ClimateFinance-Performance-of-Bangladesh-Climate-Change-Trust-Fund.pdf. Accessed 9 April 2018

Khan MH 16 April 2016. FEATURE: Unpacking Warsaw International Mechanism on Loss and Damage in the National Context of Bangladesh. Climate and Development Knowledge Network [online] Retrieved from https://cdkn.org/2016/04/feature-unpacking-warsaw-international-mech anism-loss-damage-national-context-bangladesh-2/?loclang=en_gb

Kreft S, Eckstein D, Melchior (2017) Global climate risk index: who suffers most from extreme weather events? Weather-related loss events in 2015 and 1996 to 2015. Available via https://ger manwatch.org/en/12978. Accessed 25 October 2017

Mechler R et al (2018) Science for loss and damage. Findings and propositions. In: Mechler R, Bouwer L, Schinko T, Surminski S, Linnerooth-Bayer J (eds) Loss and damage from climate change. Concepts, methods and policy options. Springer, Cham, pp 3-37

Minister of Disaster Management and Recovery (MoDMR) (2014). http://www.modmr.gov.bd/. Accessed 7 June 2017

Mirza MM (2002) Global warming and changes in the probability of occurrence of floods in Bangladesh and implications. Glob Environ Change 12(2):127-138

Nishat N, Mukherjee N, Roberts E, Hasemann A (2013) A range of approaches to address loss and damage from climate change impacts in Bangladesh. In: Loss and damage in vulnerable countries initiative. Available via www.lossanddamage.net, www.loss-and-damage.net/4825. Accessed 7 June 2017

Rabbani G, Rahman S, Faulkner L (2013) Impacts of climatic hazards on the small wetland ecosystems (ponds): evidence from some selected areas of coastal Bangladesh. Sustainability 5(4):1510-1521

Shamsuddoha M, Roberts E, Hasemann A, Roddick S (2013) Establishing links between disaster risk reduction and climate change adaptation in the context of loss and damage: policies and approaches in Bangladesh. In: Loss and damage in vulnerable countries initiative. Available via www.lossanddamage.net, www.loss-and-damage.net/download/7096.pdf. Accessed 7 June 2017

Van der Geest K, Warner K (2015) Editorial: loss and damage from climate change: emerging perspectives. Int J Global Warming 8(2):133-140 
World Bank (2010) Economics of adaptation to climate change synthesis report. Available via The World Bank Group. Available via https://siteresources.worldbank.org/.../EACC_FinalSynthesis Report0803_2010.pdf. Accessed 7 June 2017

World Bank (2011) Vulnerability, risk reduction and adaptation to climate change. Available via http://www.worldbank.org/en/results/2016/10/07/bangladesh-building-resilience-to-climatechange. Accessed 22 September 2017

Wright H (2014) What does the IPCC say about Bangladesh? In The International Centre for Climate Change and Development. Available via ICCCAD. www.icccad.net/wp-content/uploads/2015/0 1/IPCC-Briefing-for-Bangladesh.pdf. Accessed 7 June 2017

Open Access This chapter is licensed under the terms of the Creative Commons Attribution 4.0 International License (http://creativecommons.org/licenses/by/4.0/), which permits use, sharing, adaptation, distribution and reproduction in any medium or format, as long as you give appropriate credit to the original author(s) and the source, provide a link to the Creative Commons license and indicate if changes were made.

The images or other third party material in this chapter are included in the chapter's Creative Commons license, unless indicated otherwise in a credit line to the material. If material is not included in the chapter's Creative Commons license and your intended use is not permitted by statutory regulation or exceeds the permitted use, you will need to obtain permission directly from the copyright holder. 